\title{
Penerapan Sanksi Pidana Di Bidang Lingkungan Hidup Menurut UUPLH
}

\author{
Zairin Harahap
}

\begin{abstract}
Abstrak
The implementation of criminal sanction committed by the corporations is not regulated clearly on the Act No. 23/ 1997. It does not determine definitely, who must be responsible, whether the director of the corporation or the people who has the authority that can be threaten by prison sentence. Besides that, the sanction to individual who damages or pollutes the environment is higher than it 's committed by the corporation. However, it is necessarily to develop the Environmental Management Act.
\end{abstract}

\section{Pendahuluan}

Penegakan hukum lingkungan menurut Undang-undang Nomor 23 Tahun 1997 tentang Pengelolaan Lingkungan Hidup (UUPLH) tidak hanya dapat menggunakan instrumen hukum administrasi dan hukum perdata. Dengan kata lain, perbuatan pencemaran dan atau perusakan lingkungan tidak hanya dapat dijatuhi sanksi administrasi dan sanksi perdata. Tetapi, juga dapat dijatuhi sanksi pidana. Tulisan ini bermaksud untuk mengkaji penerapan sanksi pidana sebagai bagian dari sistem penegakan hukum lingkungan menurut UUPLH.

\section{Pengertian tindak pidana lingkungan hidup}

Tindak pidana lingkungan hidup terkait dengan perbuatan yang mengakibatkan terjadinya pencemaran dan atau perusakan lingkungan hidup. Oleh karena itu, perlu dikemukakan terlebih dahulu pengertian lingkungan hidup, pencemaran lingkungan hidup, dan perusakan lingkungan hidup menurut Undang-undang Nomor 23 Tahun 1997 tentang Pengelolaan Lingkungan Hidup (UUPLH). Dari pengertianpengertian tersebut, selanjutnya akan dapat dipahami kapan suatu lingkungan hidup telah

Tabel 1

\begin{tabular}{|c|c|c|}
\hline $\begin{array}{c}\text { Lingkungan Hidup } \\
\text { (Pasal } 1 \text { angka } 1 \text { UUPLH) }\end{array}$ & $\begin{array}{l}\text { Pencemaran Lingkungan } \\
\text { (Pasal } 1 \text { angka 12 UUPLH) }\end{array}$ & $\begin{array}{c}\text { Perusakan Lingkungan } \\
\text { (Pasal } 1 \text { angka } 14 \text { UUPLH) }\end{array}$ \\
\hline $\begin{array}{l}\text { Lingkungan hidup adalah kesatuan } \\
\text { ruang dengan semua benda, daya, } \\
\text { keadaan, danmakhlukhidup, temasuk' } \\
\text { manusia dan perilakunya yang mem- } \\
\text { penganuinkelangsingan perkehidipan } \\
\text { dan kesejah-teraan manusia serta } \\
\text { makhluk hidup lainya. }\end{array}$ & $\begin{array}{l}\text { Pencemaran lingkungan hidup adalah } \\
\text { masuknya atau dimasukkannya } \\
\text { makhluk hi-dup, zat, energi, dan atau } \\
\text { komponen lain ke dalam lingkungan } \\
\text { hidup oleh kegiatan manusia sehingga } \\
\text { kualitasnya tunun sampai ke tingkat ter- } \\
\text { tentu yang menyebabkan lingkungan } \\
\text { hiduptidak dapat berfungsisestai dengan } \\
\text { penuntukannya. }\end{array}$ & $\begin{array}{l}\text { Perusakan lingkungan hidup adalah } \\
\text { tindakanyang menimbulkan perubahan } \\
\text { langsung atautidak langsung terhadap } \\
\text { silat fisik dan atau hayatinya yang } \\
\text { mengakibatkanling-kungan hidup tidak } \\
\text { berfungsi lagi dalam menunjang } \\
\text { pembangunan berkelanjutan. }\end{array}$ \\
\hline
\end{tabular}




\begin{tabular}{|c|c|c|}
\hline $\begin{array}{l}\text { Unsur-unsumya: } \\
\text { - kesatuan ruang dengan semua } \\
\text { benda, daya, keadaan, dan makh- } \\
\text { luk hidup, termasuk manusia dan } \\
\text { perilakunya; } \\
\text { - yangmempengandhike-langsungan } \\
\text { perikehidupan dan kesejahteraan } \\
\text { manu-sia; } \\
\text { - serta makhluk hidup lainya. }\end{array}$ & $\begin{array}{l}\text { Unsur-unsumya: } \\
\text { - masuknya atau dimasuk-kannya } \\
\text { makhlukhidup, zat, energi, dan atau } \\
\text { komponenlainke dalam lingkungan } \\
\text { hidup; } \\
\text { - oleh kegiatan manusia; } \\
\text { - sehinggakualitasnya tu-nun sampaj } \\
\text { ke tingkattertentu; } \\
\text { - yang menyebabkan lingkungan } \\
\text { hidup tidakdapat berfungsi sesuai } \\
\text { dengan peruntukannya. }\end{array}$ & $\begin{array}{l}\text { Unsur-unsurnya: } \\
\text { - tindakan yang menimbulkan perubah } \\
\text { anlangsung atautidak langsung; } \\
\text { - terhadap sifat fisik dan atau hayatinya } \\
\text { - yang mengakibatkan lingkungan hidup } \\
\text { tidak bertungsi lagi; } \\
\text { - dalam menunjang pemba-ngunar } \\
\text { berkelanjutan. }\end{array}$ \\
\hline
\end{tabular}

mengalami pencemaran dan atau perusakan.

Dari pengertian lingkungan hidup tersebut dapat dijelaskan bahwa yang dimaksud dengan lingkungan hidup; pertama, tidak hanya hal-hal yang bersifat fisik saja, tetapi juga hal-hal yang bersifat non-fisik; kedua, tidak hanya terbatas pada makhluk yang bernyawa saja, tetapi juga termasuk makhluk yang tidak bernyawa; ketiga; manusia dan perilakunya juga merupakan bagian dari lingkungan hidup (apart of nature) bukan terpisah dari alam (apart from nature) atau dengan kata lain bahwa manusia tidak hidup dalam alam atau lingkungan hidup yang lain yang berbeda dengan makhluk-makhluk lainnya; keempat, bahwa lingkungan hidup itu tidak hanya mencakup benda-benda yang nampak (berwujud) saja, tetapi juga mencakup benda-benda yang tidak berwujud. Dengan demikian, pengertian lingkungan hidup yang dirumuskan dalam Pasal 1 angka 1 UUPL.H tersebut tidak hanya komprehensif, tetapi juga sangat luas.

Dari unsur-unsur pencemaran lingkungan hidup yang ditarik dari rumusan pencemaran lingkungan hidup sebagaimana yang disebutkan dalam Pasal 1 angka 12 UUPLH tersebut tidak hanya dapat memberikan gambaran tentang apa yang dimaksud dengan pencemaran lingkungan, kapan suatu lingkungan dapat dikatakan telah tercemar, tetapi juga sekaligus dapat memberikan penjelasan untuk membedakannya dengan kasus perusakan lingkungan.

Unsur 1 dan unsur 2 dari unsur-unsur pencemaran lingkungan hidup di atas dapat dikelompokkan ke dalam unsur penyebab terjadinya kasus pencemaran lingkungan. Sedangkan unsur 3 dan 4 adalah unsur akibat yang ditimbulkan oleh kasus pencemaran lingkungan. Untuk dapat dikatakan telah terjadi kasus pencemaran lingkungan dan sekaligus menentukan siapa polluter-nya tidak cukup hanya berhenti pada pembuktian terpenuhinya keempat unsur tersebut, tetapi juga haruslah dibuktikan adanya hubungan kausalitas dari unsur penyebab dan unsur akibat. Sebuah ilustrasi kasus dapat dikemukakan di sini; yakni sebuah perusahaan $X$ terbukti membuang limbahnya ke sungai $A$. Pada waktu yang bersamaan atau hampir bersamaan masyarakat mengeluhkan tercemarnya air sungai tersebut. Dan setelah diteliti di suatu laboratorium positif dinyatakan bahwa air sungai $A$ tercemar. Dalam contoh kasus tersebut terbukti perusahaan $X$ membuang limbahnya ke sungai $A$ dan juga terbukti air sungai A tercemar. Namun, buktibukti tersebut belum cukup kuat untuk menentukan apalagi untuk memastikan bahwa perusahaan $X$ sebagai polluter-nya. Untuk sampai pada kesimpulan seperti itu, maka berdasarkan ketentuan Pasal 1 angka 12 
UUPLH haruslah dibuktikan adanya hubungan kausalitas antara limbah yang dibuang oleh perusahaan $X$ dan penyebab terjadinya pencemaran sungai $A$. Karena, boleh jadi antara keduanya tidak memiliki hubungan kausalitas sama sekali.

Di samping itu, dalam praktik juga sering terjadi hasil laboratorium yang satu dengan hasil laboratorium yang lain dalam kaiłannya untuk membuktikan telah terjadinya pencemaran lingkungan dapat berbeda. Kasus Limbah Tahu (PN Sidoarjo, 1989) telah menunjukkannya. Hasil pemeriksaan air limbah yang dilakukan oleh Balai Teknik Kesehatan Lingkungan Surabaya menyatakan bahwa kadar limbah yang terkandung pada BOD dan COD telah melebihi ambang batas yang ditetapkan dalam SK Gubernur Jawa Timur. Semientara menurut hasil pemeriksaan yang dilakukan oleh Balai Pengembangan dan Penelitian Industri Kanwil Departemen Perindustrian Jawa Timur menyatakan bahwa kadar limbah belum melampaui baku mutu yang ditetapkan oleh Gubernur. Di samping itu, saksi dari PDAM Surabaya dan Dinas Perikanan Sidoarjo mengatakan memang benar air Kali Surabaya tercemar, namun tidak dapat memastikan bahwa hal itu disebabkan oleh limbah tahu milik terdakwa. Terhadap perbedaan hasil laboratorium tersebut, maka majelis hakim menggunakan asas "in dubio pro reo" (putusan yang menguntungkan bagi terdakwa). "

Sementara itu, dari unsur-unsur perusakan lingkungan hidup yang dikemukakan di atas, dapat disimpulkan bahwa unsur 1 dan 2 merupakan unsur penyebab terjadinya perusakan lingkungan hidup. Sedangkan unsur 3 dan 4 merupakan unsur akibat yang ditimbulkan oleh perusakan lingkungan hidup. Sebagaimana pencemaran lingkungan hidup, unsur-unsur yang terdapat pada perusakan lingkungan hidup juga merupakan unsur-unsuryang saling kait mengkait antara satu unsur dengan unsur lainnya. Oleh karena itu, untuk dapat dikatakan telah terjadinya penusakan lingkungan hidup juga menghendaki adanya pembuktian hubungan kausalitas diantara semua unsur-unsumya.

Sejauh ini, untuk membuktikan unsur 3 dan 4 dari pencemaran lingkungan hidup didasarkan kepada standar baku mutu lingkungan hidup yang ditetapkan oleh Gubernur dari daerah masing-masing. Dengan demikian, untuk membuktikannya relatif tidak menemui hambatan yang berarti. Berbeda halnya untuk membuktikan unsur 3 dan 4 dari perusakan lingkungan hidup. Sampai saat ini, apa ukuran atau kriteria yang dapat digunakan untuk membuktikan bahwa perbuatan itu telah "mengakibatkan lingkungan hidup tidak berfungsi lagi dalam menunjang pembangunan berkelanjutan" dapat dikatakan belum ada, sehingga tidak mengherankan kalau dalam praktiknya akan menimbulkan pro-kontra atau setidaktidaknya multi-interpretasi. Namun, satu hal yang kiranya perlu dikemukakan di sini adalah bahwa pada kasus penyelundupan burung Cendrawasih (PN Sorong, 1984), untuk membuktikan adanya unsur tersebut, Jaksa memberikan penekanan pada keterangan saksi ahli yang mengatakan "apabila burung Cendrawasih diambil satu ekor saja, maka peluang burung tersebut untuk berkembang biak menjadi terhenti, padahal jenis burung tersebut daya penangkarannya untuk ber-

'Siti Sundari Rangkuti,2000, Hukum Lingkungan dan Kebijaksanaan Lingkungan Nasional, Edisi Kedua, Airlangga University Press, hlm. 219-228. 
kembang biak kecil sekali dalam satu tahun".

Ketiga pasal tersebut perlu dikemukakan untuk memahami kapan suatu lingkungan hidup dapat dikualifikasikan telah terjadi pencemaran lingkungan hidup dan atau perusakan lingkungan hidup menurut UULH maupun penggantinya, yaitu; UUPLH untuk selanjutnya dapat dikualifikasikan sebagai tindak pidana lingkungan hidup. Hal ini penting dipahami, karena seperti M. Hamdan ${ }^{3}$ menyebutkan bahwa tindak pidana dalam UUPLH mencakup; (1) perbuatan pencemaran lingkungan hidup; (2) perbuatan perusakan lingkungan hidup; dan (3) perbuatan lain yang melanggar ketentuan perundang-undangan. Perbuatan sebagaimana yang disebutkan dalam nomor 3 jelas tidak ada disebutkan dalam UULH maupun penggantinya yakni; UUPLH. Oleh karena itu, sepanjang unsurunsur sebagaimana yang disebutkan dalam ketiga pasal tersebut tidak terpenuhi, maka perbuatan itu tidak dapat dikualifikasikan sebagai tindak pidana lingkungan hidup.

\section{Instrumen yang dapat diterapkan}

Tindak pidana lingkungan hidup dalam UUPLH dirumuskan pada Pasal 41, Pasal 42, Pasal 43, dan Pasal 44 sebagaimana yang akan dikutipkan di bawah ini.

\section{a. Pasal 41 UUPLH}

(1) Barangsiapa yang secara melawan hukum dengan sengaja melakukan perbuatan yang mengakibatkan pencemaran dan atau perusakan lingkungan hidup, diancam dengan pidana penjara paling lama 10 (sepuluh) tahun dan denda paling banyak Rp 500.000.000,- (lima ratus juta rupiah).

(2) Jika tindak pidana sebagaimana dimaksud pada ayat (1) mengakibatkan orang mati atau luka berat, pelaku tindak pidana diancam dengan pidana penjara paling lama 15 (lima belas tahun) dan denda paling banyak $R p$ 750.000.000,00 (tujuh ratus lima puluh juta rupiah).

Dari rumusan Pasal 41 ayat (1) UUPLH tersebut dapat diketahui bahwa ada 2 (dua) jenis tindak pidana lingkungan hidup:

1. Secara melawan hukum dengan sengaja melakukan perbuatan yang mengakibatkan pencemaran lingkungan hidup; dan atau

2. Secara melawan hukum dengan sengaja melakukan perbuatan yang mengakibatkan perusakan lingkungan hidup.

Barda Nawawi Arief, ${ }^{4}$ juga berpendapat yang sama yaitu ketentuan Pasal 41 UUPLH memuat 2 (dua) tindak pidana lingkungan hidup. Namun, beliau tidak menambahkan kata "dan atau" diantara 2 (dua) jenis tindak pidana lingkungan hidup tersebut. Kalau diperhatikan bunyi rumusan Pasal 41 UUPLH terdapat kata "dan atau" yang mempunyai implikasi bahwa perbuatan yang dapat dikualifikasikan tidak hanya perbuatan yang hanya mengakibatkan "pencemaran lingkungan hidup" atau "perusakan lingkungan hidup" saja. Tetapi, juga yang mengakibatkan "pencemaran ling-

${ }^{2}$ Ibid, hlm. 213-219. hlm. 39 .

${ }^{3}$ M. Hamdan, 2000, Tindak Pidana Pencemaran Lingkungan Hidup, Penerbit CV. Mandar Maju, Bandung,

${ }^{4}$ Barda Nawawi Arief, 2001, Masalah Penegakan Hukum dan Kebijakan Penanggulangan Kejahatan, Penerbit PT. Citra Aditya Bakti, Bandung, hlm. 88. 
kungan hidup" dan sekaligus "perusakan lingkungan hidup".

Sedangkan ancaman pidana terhadap perbuatan yang mengakibatkan terjadinya pencemaran dan perusakan lingkungan hidup menurut ketentuan Pasal 41 UUPLH tersebut tidak ada perbedaannya. Perbedaan ancaman pidana hanya terletak pada apabila perbuatan pencemaran dan atau perusakan lingkungan hidup itu mengakibatkan orang mati atau luka berat.

\section{b. Pasal 42 UUPLH}

(1) Barangsiapa yang karena kealpaannya melakukan perbuatan yang mengakibatkan pencemaran dan atau perusakan lingkungan hidup, diancam dengan pidana penjara paling lama 3 (tiga) tahun dan denda paling banyak $R p 100.000 .000,00$ (seratus juta rupiah)

(2) Jika tindak pidana sebagaimana dimaksud pada ayat (1) mengakibatkan orang mati atau luka berat, pelaku tindak pidana diancam dengan pidana penjara paling lama 5 (lima) tahun dan denda paling banyak $R p$ 150.000.000,00 (seratus lima puluh juta rupiah)

Dari rumusan Pasal 42 ayat (1) UUPLH tersebut dapat diketahui bahwa ada 2 (dua) jenis tindak pidana lingkungan hidup:

1. Karena kealpaannya atau kelalaiannya mengakibatkan pencemaran lingkungan hidup;

2. Karena keaipaannya atau kelalaiaannya mengakibatkan perusakan lingkungan hidup.

Sebagaimana Pasal 41 UUPLH di atas, dalam Pasal 42 UUPLH juga tidak dibedakan ancaman pidana pencemaran lingkungan hidup dan perusakan lingkungan hidup. Perbedaan yang ada hanya berkaitan dengan apabila pebuatan itu mengakibatkan orang mati atau luka berat, maka ancaman pidananya lebih berat.

\section{Pasal 43 UUPLH}

(1) Barangsiapa yang dengan melanggar ketentuan perundang-undangan yang berlaku, sengaja melepas atau membuang zat, energi, dan atau komponen lain yang berbahaya atau beracun masuk di atas atau ke dalam tanah, ke dalam udara atau ke dalam air permukaan, melakukan impor, ekspor, memperdagangkan, mengangkut, menyimpan bahan tersebut, menjalankan instalasi yang berbahaya, padahal mengetahui atau sangat beralasan untuk menduga bahwa perbuatan tersebut dapat menimbulkan pencemaran dan atau perusakan lingkungan hidup atau membahayakan kesehatan umum atau nyawa orang lain, diancam dengan pidana penjara paling lama 6 (enam) tahun dan denda paling banyak $\mathrm{Rp} 300.000 .000,00$ (tiga ratus juta rupiah);

(2) Diancam dengan pidana yang sama dengan pidana sebagaimana dimaksud pada ayat (1), barangsiapa yang dengan sengaja memberikan informasi palsu atau menghilangkan atau menyembunyikan atau merusak informasi yang diperlukan dalam kaitannya dengan perbuatan sebagaimana dimaksud pada ayat (1), padahal mengetahui atau sangat beralasan untuk menduga bahwa perbuatan tersebut dapat menimbulkan pencemaran dan atau perusakan lingkungan hidup atau membahayakan kesehtan umum atau nyawa orang 
lain;

(3) Jika tindak pidana sebagaimana dimaksud pada ayat (1) dan ayat (2) mengakibatkan orang mati atau luka berat, pelaku tindak pidana diancam dengan pidana penjara paling lama 9 (sembilan) tahun dan denda paling banyak $R p$ 450.000.000,00 (empat ratus lima puluh juta rupiah).

Tindak pidana lingkungan yang dirumuskan pada Pasal 43 ayat (1) adalah mencakup perbuatan-perbuatan sebagai berikut:

a. melepas atau membuang zat, energi, dan atau komponen lain yang berbahaya atau beracun masuk di atas atau ke dalam tanah, ke dalam udara atau ke dalam air permukaan;

b. melakukan impor, ekspor, memperdagangkan, mengangkut, menyimpan bahan tersebut;

c. menjalankan instalasi yang berbahaya.

Perbuatan-perbuatan tersebut dilakukan dengan:

1. melanggar ketentuan peraturan perundangundangan yang berlaku;

2. dilakukan dengan sengaja;

3. mengetahui atau sangat beralasan untuk menduga bahwa perbuatan tersebut dapat menimbulkan pencemaran dan atau perusakan lingkungan hidup atau membahayakan kesehatan umum atau nyawa orang lain.

Sedangkan tindak pidana lingkungan yang dirumuskan pada Pasal 43 ayat (2) unsurunsurnya adalah sebagai berikut:

1. dengan sengaja memberikan informasi palsu atau menghilangkan atau menyem. bunyikan atau merusak informasi yang diperlukan dalam kaitannya dengan perbuatan sebagaimana dimaksud pada ayat (1);
2. padahal mengetahui atau sangat beralasan untuk menduga bahwa perbuatan tersebut dapat menimbulkan pencemaran dan atau perusakan lingkungan hidup atau membahayakan kesehtan umum atau nyawa orang lain.

Tidak ada perbedaan ancaman pidana terhadap perbuatan yang melanggar ketentuan Pasal 43 ayat (1) dan ayat (2). Hanya saja pada ketentuan ayat (3) disebutkan bahwa apabila perbuatan sebagaimana dimaksud pada ayat (1) dan ayat (2) mengakibatkan orang mati atau luka berat, maka ancaman pidana lebih berat.

\section{d. Pasal 44 UUPLH}

(1) Barangsiapa yang melanggar ketentuan perundang-undangan yang berlaku, karena kealpaannya melakukan perbuatan sebagaimana dimaksud dalam Pasal 43, diancam dengan pidana penjara paling lama 3 (tiga) tahun dan denda paling banyak $\mathrm{Rp} 100.000 .000,00$ (seratus juta rupiah);

(2) Jika tindak pidana sebagaimana dimaksud pada ayat (1) mengakibatkan orang mati atau luka berat, pelaku tindak pidana diancam dengan pidana penjara paling lama 5 (lima) tahun dan denda paling banyak $R p$ 150.000.000,00 (se ratus lima puluh juta rupiah).

Tindak pidana lingkungan yang dirumuskan pada Pasal 44 ayat (1) UUPLH tersebut di atas, merupakan delik kealpaan (culpa) dari delik yang dirumuskan pada Pasal 43 UUPLH. Oleh karena itu, ancaman pidananya menjadi lebih ringan ketimbang apabila perbuatan itu dilakukan dengan sengaja. Sedangkan ketentuan Pasal 44 ayat (2) merupakan pemberatan ancaman pidana, karena perbuatan itu mengakibatkan 
orang mati atau luka berat. Meskipun, tindak pidana lingkungan yang disebutkan pada Pasal 44 ini merupakan delik kealpaan, namun berdasarkan ketentuan Pasal 48 UUPLH, tetap merupakan tindak pidana kejahatan bukan pelanggaran.

\section{Aparatur yang terlibat dalam penegakan hukum lingkungan}

Dalam ketentuan Pasal 40 UUPLH, secara tegas disebutkan aparatur yang terlibat dalam penegakan hukum lingkungan.

(1) Selain Penyidik Pejabat Polisi Negara Republik Indonesia, juga Pejabat Pegawai Negeri Sipil tertentu di lingkungan instansi pemerintah yang lingkup tugas dan tanggung jawabnya di bidang pengelolaan lingkungan hidup, diberi wewenang khusus sebagai penyidik sebagaimana dimaksud dalam Undang-undang Hukum Acara Pidana yang berlaku;

(2) Penyidik Pejabat Pegawai Negeri Sipil sebagaimana dimaksud pada ayat (1) berwenang:

a. melakukan pemeriksaan atas kebenaran laporan atau keterangan berkenaan dengan tindak pidana $\mathrm{di}$ bidang lingkungan hidup;

b. melakukan pemeriksaan terhadap orang atau badan hukum yang diduga melakukan tindak pidana di bidang lingkungan hidup;

c. meminta keterangan dan bahan bukti dari orang atau badan hukum sehubungan dengan peristiwa tindak pidana di bidang lingkungan hidup;

d. melakukan pemeriksaan atas pembukuan, catatan, dan dokumen lain berkenan dengan tindak pidana $\mathrm{di}$ bidang lingkungan hidup;

e. melakukan pemeriksaan di tempat tertentu yang diduga terdapat bahan bukti, pembukuan, catatan, dan dokumen lain serta melakukan penyitaan terhadap bahan dan barang hasil pelanggaran yang dapat dijadikan bukti dalam perkara tindak pidana di bidang lingkungan hidup;

f. meminta bantuan ahli dalam rangka pelaksanaan tugas penyidikan tindak pidana di bidang lingkungan hidup.

(3) Penyidik Pejabat Pegawai Negeri Sipil sebagaimana dimaksud pada ayat (1) memberitahukan dimulainya penyidikan dan hasil penyidikannya kepada Peyidik Pejabat Polisi Negara Republik Indonesia;

(4) Penyidik Pejabat Pegawai Negeri SipiI sebagaimana dimaksud pada ayat (1) menyampaikan hasil penyidikan kepada Penuntut Umum melalui Pejabat Polisi Negara Republik Indonesia;

(5) Penyidikan tindak pidana lingkungan hidup di perairan Indonesia dan Zona Ekonomi Ekslusif dilakukan oleh penyidik menurut peraturan perundang-undangan yang berlaku.

Dari ketentuan Pasal 40 tersebut, dapat diketahui bahwa aparatur yang paling berperan dalam penegakan hukum lingkungan pidana adalah Pejabat Pegawai Negeri Sipil (PPNS) yang memiliki wewenang untuk melakukan penyidikan atas terjadinya kasus pencemaran dan atau perusakan lingkungan hidup. Hasil penyidikan itu, selanjutnya disampaikan oleh PPNS kepada Penuntut Umum (Jaksa) melalui Penyidik Pejabat Polisi Negara Republik Indonesia. Apabila PPNS melakukan penyidikan, maka harus memberitahukannya kepada Penyidik Pejabat Polisi Negara Republik Indo- 
nesia. Ketentuan ayat (3) tersebut, lebih menekankan peran PPNS ketimbang Penyidik Pejabat Polisi Negara Republik Indonesia. Oleh karena itu, ketentuan ayat (3) tersebut juga harus dipahami, apabila PPNS telah melakukan penyidikan, maka Penyidik Pejabat Polisi menjadi tidak perlu lagi melakukan penyidikan. Di samping itu, PPNS juga harus segera memberitahukan Penyidik Pejabat Polisi, apabila tidak dapat atau tidak sanggup untuk melakukan tugas penyidikan, sehingga Penyidik Pejabat Polisi dapat segera untuk melakukan penyidikan. Dengan demikian, dalam melakukan tugas penyidikan atas kasus pencemaran dan atau perusakan lingkungan hidup tidak terjadi tumpang-tindih maupun sikap saling menunggu antara PPNS dan Penyidik Pejabat Polisi.

Tindak pidana di bidang lingkungan hidup menyangkut aspek yang sering bersifat teknik, sehingga memerlukan keahlian tertentu untuk melakukan penyidikan, yang sukar diharapkan dari para penyidik pejabat polisi. Oleh karena itu, menurut Koesnadi Hardjasoemantri ${ }^{5}$ diperlukan Pejabat Pegawai Negeri Sipil (PPNS) untuk mengadakan penyidikan di bidang lingkungan hidup yang diberi wewenang khusus sebagai penyidik sebagaimana dimaksud dalam KUHAP.

\section{Kategori tindak pidana lingkungan formil dan materiil}

Perumusan delik lingkungan hidup pada Pasal 41 UUPLH dan Pasal 42 UUPLH merupakan delik materiil, ${ }^{6}$ yang membawa konsekuensi pembuktian adanya hubungan kausalitas antara perbuatan perusakan dan atau pencemaran lingkungan dan akibat yang ditimbulkan, yaitu rusaknya dan atau tercemarnya lingkungan hidup yang dimaksud. Berbeda dengan Muladi ${ }^{7}$ yang mengatakan bahwa Pasal 43 UUPLH juga termasuk delik materiil, sedangkan yang memuat delik formil hanya ketentuan Pasal 44 UUPLH.

Berbeda halnya dengan Pasal 43 UUPLH dan Pasal 44 UUPLH lebih merupakan delik formil, yang membawa konsekuensi bahwa yang penting dapat membuktikan perbuatan melanggar hukumnya. Sedangkan apakah perbuatan tersebut telah mengakibatkan terjadinya perusakan dan atau pencemaran lingkungan menjadi tidaklah penting.

Berkaitan dengan delik materiel dan delik formil tersebut, Koesnadi Hardjasoemantri ${ }^{8}$ mengatakan bahwa apabila delik materie! sukar untuk membuktikan perbuatan pencemaran dan atau perusakan lingkungan, misalnya untuk membuktikan sesuatu usaha dan atau kegiatan yang mencemarkan karena baku mutu ambien sungai telah dilampaui ambang

${ }^{5}$ Koesnadi Hardjasoemantri, 2002, Hukum Tata Lingkungan, Edisi ketujuh, Cetakan ketujuh belas, Gadjah Mada University Press, Yogyakarta, halaman 408.

${ }^{6}$ Siti Sundari Rangkuti, Op. Cit, halaman 211, juga mengatakan bahwa ketentuan pasal tersebut adalah delik materiel. Pendapat yang sama juga dikemukakan oleh Barda Arief Nawawi, Op. Cit, halaman 88, dan Rachmadi Usman, 2003, Pembaharuan Hukum Lingkungan Nasional, Penerbit PT. Citra Aditya Bakti, Bandung, halaman 406.

${ }^{7}$ Muladi, Prinsip-prinsip Dasar Hukum Pidana Lingkungan dalam Kaitannya dengan UU Nomor 23 Tahun 1997, makalah disampaikan pada Seminar Nasional yang diselenggarakan oleh Fakultas Hukum Universitas Dipanegoro, Semarang, 21 Februari 1998.

${ }^{8}$ Koesnadi Hardjasoemantri, Op. Cit, halaman 410-411. 
batasnya padahal sumber pencemaran dapat berupa limbah industri, limbah domestik, dan limbah pertanian (pestisida), yang berarti multisource pollution, maka delik formil cukup dibuktikan bahwa usaha dan atau kegiatan yang bersangkutan limbahnya melampaui ambang batas yang ditetapkan oleh baku mutu efluen, yang pengukurannya dapat dilakukan di tempat penggelontoran limbah.

\section{Tindak pidana korporasi}

Tindak pidana lingkungan hidup yang dilakukan oleh korporasi diatur dalam Pasal 45 UUPLH dan Pasal 46 UUPL.H, sebagaimana yang dikutipkan di bawah ini:

\section{A. Pasal 45 UUPLH}

Jika tindak pidana sebagaimana dimaksud dalam Bab ini dilakukan oleh atau atas nama suatu badan hukum, perseroan, perserikatan, yayasan atau organisasi lain, ancaman pidana denda diperberat dengan sepertiga.

Pasal 45 UUPLH ini pada dasarnya menegaskan tindak pidana lingkungan sebagaimana yang disebutkan pada Pasal 41 , Pasal 42, Pasal 43, dan Pasal 44 UUPLH pelakunya adalah orang, sedangkan tindak pidana lingkungan yang disebutkan pada Pasal 45 UUPLH pelakunya adalah korporasi. Perbedaan lainnya terletak pada ancaman pidana dendanya, yakni; apabila tindak pidana lingkungan tersebut dilakukan oleh korporasi, maka diperberat sepertiga.

\section{B. Pasal 46 UUPLH}

(1) Jika tindak pidana sebagaimana dimaksud dalam Bab ini dilakukan oleh atau atas nama badan hukum, perseroan, perseri- katan, yayasan atau organisasi lain, tuntutan pidana dilakukan dan sanksi pidana serta tindakan tata tertib sebagaimana dimaksud dalam Pasal 47 dijatuhkan baik terhadap badan hukum, perseroan, perserikatan, yayasan atau organisasi lain tersebut maupun terhadap mereka yang memberi perintah untuk melakukan tindak pidana tersebut atau yang bertindak sebagai pemimpin dalam perbuatan itu atau terhadap kedua-duanya;

(2) Jika tindak pidana sebagaimana dimaksud dalam Bab ini, dilakukan oleh atau atas nama badan hukum, perseroan, perserikatan, yayasan atau organisasi lain, dan dilakukan oleh orang-orang, baik berdasar hubungan kerja maupun berdasar hubungan lain, yang bertindak dalam lingkungan badan hukum, perseroan, peserikatan, yayasan atau organisasi lain, tuntutan pidana dilakukan dan sanksi pidana dijatuhkan terhadap mereka yang memberi perintah atau yang bertindak sebagai pemimpin tanpa mengingat apakah orang-orang tersebut, baik berdasar hubungan kerja maupun berdasar hubungan lain, melakukan tindak pidana secara sendiri atau bersama-sama;

(3) Jika tuntutan dilakukan terhadap badan hukum, perseroan, perserikatan, yayasan atau organisasi lain, panggilan untuk menghadap dan penyerahan surat-surat panggilan itu ditujukan kepada pengurus di tempat tinggal mereka, atau di tempat pengurus melakukan pekerjaan yang tetap;

(4) Jika tuntutan dilakukan terhadap badan hukum, perseroan, perserikatan, yayasan atau organisasi lain, yang pada saat penuntutan diwakili oleh bukan pengurus, 
hakim dapat memerintahkan supaya pengurus menghadap sendiri di pengadilan. Berdasarkan ketentuan Pasal 46 UUPLH tersebut, maka yang dapat dimintakan pertanggungjawaban pidana atau dituntut dan dijatuhi pidana apabila terjadi kasus pencemaran dan atau perusakan lingkungan hidup adalah:

1. badan hukum, perseroan, perserikatan, yayasan atau organisasi lain;

2. mereka yang memberi perintah untuk melakukan tindak pidana atau yang bertindak sebagai pemimpin dalam perbuatan itu; atau

3. kedua-duanya.

\section{Asas Subsidiaritas (Ultimum Remedium) dalam UUPLH}

Dalam angka 7 Penjelasan Umum UUPLH disebutkan "Sebagai penunjang hukum administrasi, berlakunya ketentuan hukum pidana tetap memperhatikan asas subsidiaritas, yaitu bahwa hukum pidana hendaknya didayagunakan apabila sanksi bidang hukum lain, seperti sanksi administrasi dan sanksi perdata, dan alternatif penyelesaian sengketa lingkungan hidup tidak efektif dan atau tingkat kesalahan pelaku relatif berat dan atau akibat perbuatannya relatif besar dan atau perbuatannya menimbulkan keresahan masyarakat".

Ketentuan angka 7 Penjelasan Umum UUPLH yang memuat asas subsidiaritas tersebut, menimbulkan beberapa persoalan:

1. Asas subsidiaritas tersebut sama sekali tidak diatur pada pasal dalam Batang Tubuh, tetapi hanya diatur pada Penjelasan Umum. Sejauh ini, kekuatan mengikat suatu penjelasan dari suatu peraturan perundangundangan masih menjadi perdebatan. Sebagian pakar mengatakan tidak mempunyai kekuatan mengikat dan yang mempunyai kekuatan mengikat hanyalah pasal-pasal dalam Batang Tubuh, karena sifat normatifnya. Sedangkan, sebagian pakar lainnya mengatakan mempunyai kekuatan mengikat, karena sifat interpretasi autentiknya. Di samping itu, baik pasal-pasal pada Batang Tubuh maupun Penjelasan sama-sama dibuat dan dibahas dalam sidang DPR;

2. Kalimat yang menyatakan; (a) apabila sanksi administrasi, sanksi perdata, dan alternatif penyelesaian sengketa lingkungan "tidak efektif"; (b) "tingkat kesalahan pelaku relatif berat"; (c) akibat perbuatannya relatif besar"; atau (d) perbuatannya menimbulkan keresahan masyarakat", tidak mempunyai ukuran atau kriteria yang jelas. Implikasinya sudah barang tentu penerapan asas subsidiaritas itu menjadi sangat tergantung dari penafsiran aparat penegak hukumnya dalam hal ini PPNS dan Penyidik Pejabat Polisi. Dalam kaitannya dengan penerapan asas subsidiaritas tersebut, Hamrat Hamid ${ }^{9}$ mengatakan bahwa proses perkara pidana lingkungan sebagai bagian dari penegakan hukum dapat didahulukan atau diutamakan pelaksanaannya dalam hal-hal sebagai berikut:

a. Upaya-upaya dan sanksi-sanksi administratif yang dijatuhkan tidak meredakan kebandelan tersangka, pelanggaran yang dilakukannya bahkan kian meningkat;

b. Tidak ada faedahnya lagi menempuh jalan penindakan administratif maupun perdata,

\footnotetext{
${ }^{9}$ Sebagaimana dikutip M: Hamdan, Op. Cit, halaman 101-102.
} 
karena perusakan/pencemaran yang terjadi sudah tidak mungkin dapat diperbaiki lagi;

c. Tidak ada pilihan penindakan selain dari pidana;

d. Penindakan melalui proses pidana, tindakan yang sangat strategis untuk menangkal pelaku pencemaran lainnya;

e. Penundaan penindakan tersangka melalui proses pidana secara psikologis dapat menjatuhkan wibawa hukum dan wibawa pemerintah;

f. Pelanggaran terjadi sebagai hasil kolusi dengan oknum-oknum pejabat setempat yang menyinggung perasaan masyarakat atau menyebalkan masyarakat.

\section{Penerapan sanksi pidana}

Berdasarkan ketentuan Pasal 41, 42, 43, 44, 45, 46, dan Pasal 47 UUPLH dapat diketahui bahwa jenis-jenis sanksi pidana yang dapat diancamkan terhadap pelaku perusakan dan atau pencemaran lingkungan adalah pidana penjara, denda, dan atau tindakan tata tertib. Jenis-jenis sanksi pidana yang berupa pidana penjara dan denda bersifat komulatif. Sedangkan jenis sanksi pidana yang berupa tindakan tata tertib lebih bersifat diskresi, sehingga sepenuhnya diserahkan kepada kebijaksanaan dari penyidik. Pasal $41,42,43$, dan Pasal 44 UUPLH berkaitan dengan sanksi pidana yang dapat diancamkan kepada pelaku perusakan atau pencemaran lingkungan yang dilakukan oleh orang. Pasal 45 dan Pasal 46 UUPLH adalah sanksi pidana yang dapat diancamkan kepada pelaku perusakan dan atau pencemaran lingkungan yang dilakukan oleh korporasi. Sedangkan ketentuan Pasal 47 adalah sanksi pidana yang dapat diancamkan kepada pelaku perusakan dan atau pencemaran lingkungan yang dilakukan baik oleh orang maupun korporasi.

Sementara itu, berdasarkan rumusan Pasal 45 dan Pasal 46 UUPLH yang mengatur tentang tindak pidana lingkungan yang dilakukan oleh korporasi tidak memiliki kejelasan tentang apakah pemimpin korporasi dan atau mereka yang memberi perintah dapat diancam dengan sanksi pidana yang berupa pidana penjara. Memang, dalam Pasal 46 UUPLH disebutkan kemungkinan pemimpin korporasi dan atau mereka yang memberi perintah dijatuhi sanksi pidana baik berupa pidana penjara dan denda (sebagaimana sanksi pidana yang terdapat dalam Pasal 41 Pasal 44 UUPLH) dan atau tindakan tata tertib (sebagaimana yang terdapat dalam Pasal 47 UUPLH). Namun, hai itu menjadi rancu dengan ketentuan Pasal 45 UUPLH yang menyebutkan bahwa jika perbuatan itu dilakukan oleh korporasi ancaman pidana dendanya diperberat dengan sepertiga.

Kerancuan itu dapat dijelaskan bahwa ancaman sanksi yang terdapat dalam Pasal 41 - 44 UUPLH bersifat komulatif, sementara apabila mengacu kepada Pasal 45 dan 46 UUPLH terjadi pemisahan antara ancaman pidana penjara yang ditujukan kepada pemimpin korporasi dan atau kepada mereka yang memberi perintah, sedangkan ancaman dendanya ditujukan kepada korporasinya. Atas dasar itu, maka sanksi pidana yang sudah jelas dapat diancamkan hanya terhadap korporasi, yaitu berupa pidana denda yang diperberat dengan sepertiga, sedangkan terhadap pemimpin korporasi dan atau mereka yang memberi perintah tidak jelas apakah hanya dapat dikenakan pidana penjara saja, atau pidana penjara dan denda, atau pidana 
penjara, denda, dan tindakan tata tertib. Jika hanya dikenakan kemungkinan yang pertama, maka hal itu tidak sejalan dengan ketentuan Pasal 41 - 44 UUPLH yang menganut sifat komulatif. Sementara, apabila dikenakan kemungkinan kedua, berarti terjadi penggandaan penjatuhan sanksi pidana yang berupa denda, yakni; denda yang dijatuhkan kepada korporasi dan kepada pemimpin korporasi dan atau mereka yang memberiperintah. Begitu juga, apabila dikenakan kemungkinan yang ketiga, menjadi tidak rasional, karena pemimpin korporasi dan atau mereka yang memberi perintah tidak mungkin dapat dikenakan sanksi pidana yang berupa tindakan tata tertib.

Di samping itu, korporasi juga dapat dikenakan sanksi yang berupa tindakan tata tertib sebagaimana yang disebutkan dalam Pasal 47 UUPLH. Untuk jenis sanksi pidana yang terakhir tersebut relatif sifatnya. Dengan kata lain, tidak setiap kasus pidana lingkungan otomatis dikenakan sanksi pidana yang berupa tindakan tata tertib tersebut.

Berangkat dari rumusan Pasal 45 dan Pasal 46 UUPLH di satu pihak dan rumusan Pasal 41. Pasal 42, Pasal 43, dan Pasal 44 UUPLH di pihak lain, maka jelas sekali bahwa perusakan dan atau pencemaran lingkungan yang dilakukan oleh orang ancaman hukumannya menjadi lebih berat daripada yang dilakukan oleh korporasi. Ancaman hukuman yang dapat dikenakan kepada orang yang melakukan perusakan dan atau pencemaran lingkungan terdiri atas pidana penjara dan denda, dan atau tindakan tata tertib. Tidak jelas, apa yang menjadi latar belakang dari para pembuat UUPLH, sehing-ga ancaman hukuman terhadap perusakan dan atau pencemaran lingkungan yang dilakukan oleh orang lebih lengkap dan lebih jelas (pidana penjara dan denda, dan atau tindakan tata tertib) daripada apabila pelakunya adalah korporasi.

\section{Kesimpulan}

UUPLH menganut asas subsidiaritas dalam penerapan sanksi pidana terhadap pelaku pencemaran dan atau perusakan lingkungan hidup. Namun, apabila dicermati pengertian asas tersebut sebagaimana yang disebutkan dalam angka 7 Bagian Penjelasan Umum UUPLH, maka dapat disimpulkan bahwa penerapan asas tersebut menjadi sangat fleksibel. Sehingga, penjatuhan sanksi administrasi, penyelesaian sengketa di luar pengadilan maupun melalui pengadilan tidak dengan serta merta menjadi penghalang penuntutan pidana terhadap pelaku pencemaran dan atau perusakan lingkungan hidup.

Ketidaktegasan Pasal 45 dan Pasal 46 UUPLH tentang dapat tidaknya korporasi dijatuhi sanksi pidana yang berupa pidana penjara membuat ketentuan Pasal 45 dan Pasal 46 UUPLH tersebut mengandung kelemahan. Di samping itu, jenis-jenis sanksi pidana yang berupa tindakan tata tertib sebagaimana yang disebutkan dalam Pasal 47 UUPLH sedikit banyak rancu dengan jenisjenis sanksi administrasi yang disebutkan dalam Pasal 25 ayat (1) UUPLH. Oleh karena itu, untuk penyempurnaan UUPLH di masa yang akan datang ketentuan-ketentuan yang terdapat dalam pasal-pasal tersebut perlu mendapatkan perhatian

\section{Daftar Pustaka}

Barda Nawawi Arief, 2001, Masalah Penegakan Hukum dan Kebijakan Penanggulangan Kejahatan, Penerbit PT. Citra Aditya 
Bakti, Bandung.

Koesnadi Hardjasoemantri, 2002, Hukum Tata Lingkungan, Edisi ketujuh, Cetakan ketujuh belas, Gadjah Mada University Press, Yogyakarta.

M. Hamdan, 2000, Tindak Pidana Pencemaran

Lingkungan Hidup, Penerbit CV. Mandar Maju, Bandung.

Muladi, Prinsip-prinsip Dasar Hukum Pidana Lingkungan dalam Kaitannya dengan UU Nomor 23 Tahun 1997, makalah disampaikan pada Seminar Nasional yang diselenggarakan oleh Fakultas Hukum Universitas Dipanegoro, Semarang.

Rachmadi Usman, 2003, Pembaharuan Hukum Lingkungan Nasional, Penerbit PT. Citra Aditya Bakti, Bandung.

Siti Sundari Rangkuti, 2000, Hukum Lingkungan dan Kebijaksanaan Lingkungan Nasional, Edisi Kedua, Airlangga University Press, Surabaya. 